\title{
Using Communicative Games to Improve Students' Speaking Skill at SMPN 2 LAMASI
}

\author{
Fibri Indira Lisanty AD \\ indirafibrie@uncp.ac.id \\ Jumriani D.M \\ Jumriani1@gmail.com
}

\section{Cokroaminoto Palopo University}

\begin{abstract}
This research aims to determine the effectiveness of communicative games that can improve students' speaking skills in class VIII at SMPN 2 Lamasi. The method that is applied in this research is a pre-experimental design. The population in this research is the seventh-grade students of SMPN 2 Lamasi, and the total sample is 15 students. The research uses a cluster random sampling technique in determining the sample. The instrument of this research is speaking. The results of this research indicated that after using the communicative games to improve students' speaking skills of SMPN 2 La masi increases. This shows that there are significant differences between student scores in pre-tests and post-test. The mean score of the students' pre-test is 37.47 and 81.47 in the post-test. So, there is significant different between the result of pre-test and post-test after the treatment. Therefore, the researcher concludes that communicative games is effective in teaching speaking at eight grade of SMPN 2 Lamasi.
\end{abstract}

Keywords: Communicative Games; Improving; Talking

\section{INTRODUCTION}

Responding to this did not rule out the possibility that even in Indonesia knowledge and knowledge of English is one of the basic sciences that must be possessed by every individual, especially for students. English itself is certainly very important to master where English is a foreign language in Indonesia which is also one of the compulsory subjects that must be taught in junior high schools as implied by government regulation No. 19/2005 article 6 paragraph 1 concerning the scope of subjects at each level of education in the curriculum.

English students because it is significant and its use is to support communication skills. Unfortunately in teaching and learning to speak the truth to students of SMPN 2 Lamasi, most students have difficulty speaking their English. According to the observations of teachers and students they feel difficulty in speaking English because they feel afraid of making mistakes or being laughed at by their friends due to imperfect pronunciation, as well as lack of confidence in students speaking English, they feel tense and assume it is a difficult thing to do because the way of teaching is too monotonous, so that makes students feel pressured and 
bored in learning and considers speaking English is a difficult thing to do because the teacher asks students to speak by following the existing texts/concepts.

Therefore this research considers that it is very important to find alternative ways of learning and teaching to create more interesting learning techniques related to student conditions. Communicative games are an alternative way to overcome students 'difficulties in speaking English and can improve students' speaking skills. However, talking about communicative games cannot be separated from those two terms; "Communicative" and "guaranteed". The word communicative refers to the communicative approach in which teaching and learning activities avoid concentration or focus on grammar and vocabulary, but emphasize the importance of the function of language itself. In short, it can be concluded that communicative games are a series of well-designed activities that stimulate student interaction in the classroom. This game requires students to express themselves actively in class in terms of speaking which can trigger their selfconfidence which that formed automatically because the concept is in building habits of interacting with each other in English.

\section{LITERATURE REVIEW}

\section{Previous Study}

Yen Hui Wang (2010) in her thesis entitled "Using Communicative Language Games in Teaching and Learning in Elementary Schools in Taiwan". The results of this study provide encouraging evidence to show that Taiwanese school teachers generally appreciate the benefits and value of communicative play activities in teaching English. This finding also teaches that if facing students with different backgrounds, learning styles, needs, and expectations, teachers must be aware of the varying needs of each student and can be more flexible in using their communicative games to maximize the effects of education.

Friska Arismayang (2016) in her thesis entitled "improving students' speaking abilities through communication games, role plays and peer feedback". Based on data analysis, test results were obtained which showed that students' speaking skills improved. They focus on the same area of improving students' speaking skills, but this research is limited to communicative games.

\section{Speaking}

Speaking is a productive listening skill. Speaking is the process of making verbal words and sentences impossible. With speaking skills, everyone can convey their ideas, opinions, and thoughts about the world. By speaking, everyone can have an easy way to communicate with each other directly or indirectly. As said by Brown and Yale (89:14) That expressing expressions requires requests for information, services, and so on.

Mackey (in Magiono, 2007: 13) defines speaking as an oral expression that involves not only using the correct pattern of rhythm and intonation but also the 
right sequence to convey the true meaning. Chaney (1998: 13) believes speaking is a process of building and sharing meaning using verbal and nonverbal symbols, in various contexts. The language was first used, this means that speaking is the basic competition and the most important language skills such as the statements mentioned by Tupan (1995: 4). Besides that, Harmer (2007) states that speaking is a skill that is an important part of daily life, it is a line for everyone to create social relationships as human beings so that they need to be developed and practiced independently in the grammar curriculum. From the many definitions above it can be concluded clearly, that speaking is the process of conveying and expressing ideas, opinions, or feelings to others by using words or articulation sounds to be able to inform things that can be learned by using several teaching and learning methodologies.

\section{Communicative Activities}

Every student speaking must be based on communicative activities that achieve two important learning needs. The teacher must be able to encourage students to gain language knowledge and make them able to have their language in real life. Lieshoff, stated that communicative activities include everything that can encourage and make students speak and also listen to their peers. To be able to achieve results, students must be able to interact, which means that they not only do the activity of talking to someone but also they must be able to listen to what is said and conveyed by the interlocutors and respond to it. In implementing communicative activities, Harmer (2001: 85) states that activities in CLT usually bring students into real or realistic communication activities, where the accuracy of the language they use is less important than the achievement of the communicative tasks they perform. Littlewood (1981) classifies two types of communicative activities carried out by communicative language students. They are functional communicative activities and social interaction activities.

\section{METHODS}

\section{Design and Sample}

This research applies a pre-experimental method that aims to find out whether there is an increase in students' ability to speak English by using communicative games. This research is consists of one group and the researcher provides a pretest and post-test design. This research is conducted in October 2020 the academic year 2019/2020. The location of this research was conducted at SMPN 2 Lamasi. The population in this research is the students from SMPN 2 Lamasi. The total number of students 32 people. This researcher uses a random sampling technique. The number of samples is 15 students. The researcher chooses randomly based on the student attendance list. This research uses text to speak as a research instrument. The speaking test is used in pre-test and post-test, the results have been recorded and transcribed. This pre-test aims to see the students' speaking 
ability before training and teaching, while the post-test is conducted at the end of the activity to determine the effectiveness of communicative games.

\section{Instrument and Procedure}

This research uses speaking test as the instrument of the research. To collect the data needed in this research, researchers used the following procedure:

1. First, give pre-test, the researcher introduced her/himself to students then explained the reason the researcher came in their class. Then, the researcher gave a pre-test to students to find out their basic knowledge of speaking skills in English. The pre-test is the ability of students before giving treatment. The initial test takes 90 minutes, the researcher would provided topics and questions based on this topic to students. Students were asked to introduce themselves one by one using English. Students' ability to talk about fluency, accuracy, grammar, and completeness of the vocabulary of students' speaking results.

2. Start giving care activities and guidance to students after the pre-test and before the post-test. This is done during 4 meetings with students in the class to give students material about communicative play in language learning. Each meeting took 60 minutes or more and during that time the researcher provide various learning activities using communicative games to students. During treatment, students are guided with accuracy, fluency, and the need to improve speaking skills.

3. Giving post-test

After providing treatment, students be given a post-test at the last meeting to find out whether the use of communicative games is able or not in improving students' speaking skills using English. Research gives questions to students in the form of English about their identity. The next research compares what there is a better chance of after treatment by research to students.

\section{Data Analysis}

Scoring The Students'

$$
\text { Score }=\frac{\text { The number of studer }}{\text { Total point }} \times 100
$$

Classifying student scores into some classification below :
a. 86-100: Classified as excellent
b. 71-85: Classified as very good
c. 56-70: Classified as good
d. 41-55: Classified as fairly good
e. 26-40: Classified as poor
f. <25: Classified as a very poor

(Dikbud in Asriana, 2012:50)

Calculating the percentage of score classification

$$
\mathrm{P}=\stackrel{\mathrm{F}}{\mathrm{X}} 100
$$




$$
\begin{aligned}
& \text { Where : } \\
& \mathrm{P}=\text { Percentage } \\
& \mathrm{F}=\text { Frequency } \\
& \mathrm{N}=\text { Number of Sample }
\end{aligned}
$$

(Gay, 1981:298)

\section{FINDINGS AND DISCUSSION}

In this part, the researcher presents the students' score, the students' score classification the mean score, the standard deviation of pre-test and post-test. Furthermore, in this parts, the researcher also presents the result of a significant difference between pre-test and post-test after giving the speaking test. The Students' Score in Pre-test and Post-test The Students' score of speaking before using communicative games in the pre-test and a post-test show in the following table :

Table 1. The students' score in pre-test

\begin{tabular}{|c|c|c|}
\hline No. & Students' Code & Total Score \\
\hline 1. & S-01 & 40 \\
2. & S-02 & 40 \\
3. & S-03 & 46 \\
4. & S-04 & 53 \\
5. & S-05 & 33 \\
6. & S-06 & 40 \\
7. & S-07 & 33 \\
8. & S-08 & 46 \\
9. & S-10 & 53 \\
10. & S-10 & 46 \\
11. & S-11 & 46 \\
12. & S-12 & 40 \\
13. & S-13 & 40 \\
14. & S-14 & 33 \\
15. & S-15 & 26 \\
\hline Total & & $\mathbf{8 4 3}$ \\
\hline
\end{tabular}

Table 1 shows the students' scores in the pre-test. From the data above, it can be seen that there was 1 students' get $40 ; 1$ students' get $46 ; 1$ students ' get 33 ; 5 student get $60 ; 3$ students' get $53 ; 1$ students` get $80 ; 1$ students` get 66 ; and 1 students' get 73 . From the data above, it can be seen that the highest score from all of the students in the pre-test was 80, and the lowest score was 33 .

Table 2 : The Students' score of speaking after using communicative games in pre-test and post-test show in the following table :

No. Students' Code Total




\begin{tabular}{lll}
\hline 1. & S-01 & 86 \\
2. & S-02 & 93 \\
3. & S-03 & 86 \\
& & \\
4. & S-04 & 93 \\
5. & S-05 & 86 \\
6. & S-06 & 93 \\
7. & S-07 & 66 \\
8. & S-08 & 93 \\
9. & S-09 & 80 \\
10. & S-10 & 73 \\
11. & S-11 & 80 \\
12. & S-12 & 73 \\
13. & S-13 & 80 \\
14. & S-14 & 60 \\
15. & S-15 & 60
\end{tabular}

\section{Total}

1.202

Data table 2 shows the students' scores in the post-test. From the data above, it can be seen that there was 2 student gets $73 ; 1$ student gets $66 ; 2$ student gets 60 ; 3 student gets $80 ; 3$ student gets 86 ; and 4 student gets 93 From the data above, it can be seen that the highest score from all of the student in post-test was 93, and the lowest score was 66.

The rate percentage of the students' in the pre-test.

Table 3. Students' score in the pre-test.

\begin{tabular}{llccc}
\hline No. & Classification & Score & Frequency & Percentage $\%$ \\
\hline 1. & Excellent & $96-100$ & 0 & 0 \\
2. & Very Good & $86-95$ & 0 & 0 \\
3. & Good & $76-85$ & 1 & $6 \%$ \\
4. & Average & $66-75$ & 7 & $46 \%$ \\
5. & Fair & $56-65$ & 0 & 0 \\
6. & Poor & $45-55$ & 5 & $33 \%$ \\
7. & Very Poor & $0-45$ & 2 & $13 \%$ \\
\hline & Total & & 15 & $100 \%$ \\
\hline
\end{tabular}

Based on table 3, we can see that before giving a treatment by using communicative games, there are no students who get an excellent and very good classification. Meanwhile there are $1(6 \%)$ students who get good, there are 7 $(46 \%)$ students get average, there are no students get fair, there are $5(33 \%)$ students get poor and there are $2(13 \%)$ students get very poor classification. The data above indicate that the students were weak in speaking skill before treatment to be done.

The mean score and standard deviation of the students in pre-test and post-test. 
Table 4. The mean score and standard deviation of the students in pre-test and post-test.

\begin{tabular}{ccc}
\hline $\begin{array}{c}\text { Test } \\
\text { deviation }\end{array}$ & Mean score & Standard \\
\hline Pre-test & 41.00 & 7.606 \\
Post-test & 80.13 & 11.581 \\
\hline
\end{tabular}

In table 4 , it can be seen the comparison mean score between pre-test and posttest. The researcher concludes that the using realize media can increase the students Speaking skill. The mean score of the students in the pre-test was 41.00. The mean score of the students in the post-test was 80,13.It means that the mean score before giving treatment (pre-test) was lower than after giving treatment (post-test). Therefore, it can be concluded that there was an improving score of the students after giving treatment. It is also supported by the standard deviation. The standard deviation of the pre-test was 7.606 lower than the standard deviation of the post-test was 11,581. T-test significance different between pre-test and posttest. To know whether the pre-test and post-test were significantly different, the researcher used t-analysis. The result of statistical analysis for the level of the significance $(a)=0.05$ with degree freedom $(\mathrm{df})=19$, where :

Table 5. T-test significance different between pre-test and post-test

\begin{tabular}{ccc}
\hline Variables & T-test & T-value \\
\hline $\mathrm{X} 2-\mathrm{X} 1$ & 0,00 & 0,05 \\
\hline
\end{tabular}

From the table above, it can be seen the value of the T-test was lower than T-value or 0,00 smaller than 0,05 . It means that using communicative games can increase the ability of speaking skills of students.

\section{CONCLUSION}

Based on the results of the research and discussion that has been described in the previous discussion, conclusions can be drawn through the tests found from the data analysis that has been carried out, namely the results of the initial test on the sample that obtained a value greater than 75 (capable), namely 9 students (42.9\%) and students who scored smaller than 75 (unable), namely 12 students $(57.1 \%)$. Then based on the results of the final test of the experimental class using the communicative games, it shows that students who get a score greater than 75 (capable) are 20 students $(95.3 \%)$ and students who get a score smaller greater than 75 (unable), namely 1 student $(4.8 \%)$. Thus, the results of students' speaking after the use of communicative games have been completed or have been adequate if confirmed with the KKM of the English school subjects. So, it can be concluded that using communicative games techniques can improve students' speaking skills and this technique can be an effective learning tool for English teachers in the class VIII SMPN 2 Lamasi, Luwu.

\section{REFERENCES}


Arismayang, F. 2016. Improving Students Speaking Skill Through Communicative Games, Role Plays, and Peer Feedback. Vol. 1, No. 2, 2016 158-165, http://dx,org/10.22236/JER_Vol1Issue2. Jakarta. Indonesia.

Boekaerts, Monique. 2002. Motivation to learn. Internatonal Academy of Education. Zwitzerland.

Brown, H, D.1994. Teaching by principles. An interactive approach to language pedagogy. Upper Sadle River, Prentice Hall Regents, New Jersey.

British Council. 2015. ELT Guide-1 : communicative games. NFER. Edinburgh.

Brow n, H, D. 2001. Teaching by principles. An interactive approach to language pedagogy. San Fransisco University. San Fransisco.

Celce Murcia, M.(ed). 2001. Teaching English as a second or foreign language, $3^{\text {rd }}$ edition. MA : Heinle\&Heinle.Boston.

Chaney, A.L., T.L. Burke, Teaching Oral Communication in Grades K-8. Boston: Allyn and Bacon, 1998. Journal of Engineering Technology and Education, Vol. 7, No. 1. March 2010, pp.126-142.

Harmer, J. 2001. The Practice Of English Language Teaching ( $3^{\text {rd }}$ Ed.). London and Longman Group. New York.

Khrasen, S. D. 1982. Principles and Practice in Secon Language Acquistion. Pergamon. Oxford

Nunan, D. 1999. Secon Language Teaching and Learning. Assachusetts, Heinle \& Heinle Publishers. Boston.

Nunan, D. 2003. Practical English Language Teaching. McGrawHill. NY

Novianti, R. 2018. Improving speaking skill students through communicative games at the third year of SMPN 2 Walenrang. Thesis Cokroaminoto Palopo University.

O’Malley, J. M and Pirce L.V. 1996. Authentic Assessment for English Language Learners. AddisonWesley Publishing Company.

Ur, P. 1996. A Course in Language Teaching: Practice and Theory. Cambridge University Press. Cambridge

Wallace, M. J. 1987. Teaching Vocabulary. Heineman Education Books. Ltd. London

Wang, Yen-Hui. 2010. Using communicative language games in teaching and learning in Taiwanese primary school. Journal of Engineering Technology and Education: Vol. 7, No. 1, pp. 126-142

Willis, J. 1996. A Framework for Task-Based Learning. Longman. London 